\title{
PENGEMBANGAN MEDIA PEMBELAJARAN ONLINE TERHADAP KEMAMPUAN KONEKSI MATEMATIS MAHASISWA \\ ${ }^{1)}$ Diki Mulyana, ${ }^{2)}$ Mochammad Taufan \\ ${ }^{1,2)}$ Program Studi Pendidikan Matematika, Universitas Wiralodra Indramayu \\ ${ }^{1)}$ diki.mulyana@unwir.ac.id, ${ }^{2)}$ mochammad.taufan@unwir.ac.id
}

\section{Received:}

28/08/2020

Accepted :

$01 / 09 / 2020$

Published :

02/09/2020

\begin{abstract}
This research aims to develop and produce a valid and practical online learning media to students' mathematical connection skills. Specific targets to be achieved in this research specifically to increase in the mathematical connection ability of students of the Wiralodara Indramayu University mathematics study program for the Secondary Education Mathematics Capita Selecta course. This goal is based on the problem that the learning media used during lectures is learning media that has not been developed by lecturers, preparing for the 4.0 revolution and online learning is one of the impacts of Covid-19. From these problems resulted in the low ability of students in mathematical connections of the Secondary Education Mathematics Capita Selecta course. This type of research is development research using the Plomp model which has four stages, (1) initial stage, (2) design stage, (3) realization and construction stage, and (4) testing, evaluation, and revision. Meanwhile, the device developed was the online learning media for the Secondary Education Mathematics Capita Selecta course. The development of learning media that has been compiled is then validated with validation sheet instruments by expert validators and the criteria are set until the criteria are valid. Limited trials with questionnaire sheet instrument student responses and lecturer responses in Secondary Education Mathematics Capita Selecta course to measure practicality. The data in this study were obtained through expert validation instrument sheets and questionnaires. To achieve valid and practical criteria, it is processed descriptively. The targeted output is to produce online learning media in mathematics education for learning secondary mathematics selective capita courses.
\end{abstract}

Keywords: online learning media, mathematical connection ability, valid and practical.

\begin{abstract}
Abstrak
Penelitian ini bertujuan untuk mengembangkan dan menghasilkan suatu media pembelajaran online yang valid dan praktis dalam terhadap kemampuan koneksi matematis mahasiswa. Target khusus yang ingin dicapai dalam penelitian ini yakni meningkatnya kemampuan koneksi matematis mahasiswa program studi matematika Universitas Wiralodara Indramayu untuk mata kuliah Kapita Selekta Matematika Pendidikan Menengah. Tujuan tersebut didasarkan pada permasalahan bahwa media pembelajaran yang digunakan pada saat perkuliahan adalah media pembelajaran yang belum dikembangkan oleh dosen, mempersiapkan mengahadapi revolusi 4.0 dan kondisi pembelajaran yang menggunakan daring merupakan salah satu dampak dari Covid-19. Dari permasalahan tersebut mengakibatkan rendahnya kemampuan mahasiswa dalam koneksi matematis mata kuliah kapita selekta matematika menengah. Jenis penelitian yang digunakan merupakan penelitian pengembangan dengan menggunakan model Plomp yang telah dimodifikasi menjadi empat tahap, yaitu: (1) tahap investigasi awal, (2) tahap desain, (3) tahap realisasi dan konstruksi, dan (4) tes, evaluasi, dan revisi. Sedangkan Perangkat yang dikembangkan yakni media pembelajaran online mata kuliah kapita selekta matematika menengah. Pengembangan media pembelajaran yang telah disusun selanjutnya divalidasi dengan instrumen lembar validasi oleh validator ahli dan praktisi sampai memenuhi kriteria valid. Selanjutnya dilakukan uji coba terbatas dengan instrumen lembar angket respon mahasiswa dan respon dosen mata kuliah kapita selekta matematika menengah untuk mengukur kepraktisan. Data dalam penelitian ini diperoleh melalui instrumen lembar pengamatan validasi ahli dan angket. Untuk memperoleh kriteria valid dan praktis diolah secara deskriptif. Luaran yang di targetkan yaitu menghasilkan media pembelajaran online di pendidikan matematika untuk pembelajaran mata kuliah kapita selekta matematika menengah.
\end{abstract}

Kata Kunci: Media pembelajaran online, Kemampuan Koneksi Matematis, Valid dan Praktis. 


\section{Pendahuluan}

Menghadapi revolusi industri 4.0 telah memberikan tantangan dalam dunia pendidikan di Indonesia. Beberapa catatan menyebutkan bahwa mutu pendidikan di Indonesia masih rendah bila dibandingkan dengan mutu pendidikan di negara lain. Kemendikbud merilis hasil PISA (the Program for International Student Assessment) adalah ujian di seluruh dunia yang diselenggarakan setiap tiga tahun sekali untuk mengukur kecerdasan pelajar sekolah berusia 15 tahun di 72 negara. Sekitar 540.000 siswa dari seluruh dunia termasuk dari Indonesia mengikuti ujian yang di selenggarakan oleh The Organization for Economic Co-operation and Development (OECD) pada tahun 2015, Indonesia berada di peringkat 62. Catatan lain juga menyebutkan bahwa dalam berbagai diskusi pendidikan di Indonesia, khususnya pendidikan matematika, salah satu yang menjadi sorotan adalah mutu pendidikan matematika yang diduga tergolong memperihatinkan.

Keadaan tersebut tentu sangat ironis bila dikaitkan dengan peranan matematika sebagai dasar untuk mengembangkan ilmu pengetahuan dan teknologi. Untuk memfasilitasi belajar mandiri mahasiswa, penggunaan media pembelajaran merupakan salah satu alternatif dalam proses pengembangan pembelajaran untuk menjadi lebih baik. Saluky (2016) mengatakan internet atau interconnection and networking merupakan sebuah jaringan informasi global yang memungkinkan penggunanya terhubung dengan pengguna lainnya melalui media komputer atau laptop atau gadget lainnya yang memiliki sistem wireless. Internet yang sudah memasuki bidang pendidikan dalam kurun waktu dekade ini memungkinkan terjadinya pembelajaran berbasis internet dengan komputer sebagai medianya. Melalui penggunaan media pembelajaran online maka, mahasiswa secara mandiri lebih dapat memahami materimateri tertentu yang terkesan abstrak dan tidak mudah divisualisasikan. Selain itu, diharapkan mahasiswa sebagai calon guru matematika termotivasi dan mampu berperan aktif pada pembelajaran di kelas.

Kusumah (dalam Wardani, 2013) berpendapat, "Pada umumnya mahasiswa mempunyai rasa penasaran yang tinggi untuk mencoba sesuatu yang baru, termasuk teknologi yang dalam dasawarsa ini sedang digandrungi remaja dan anak-anak sekolah." Pembelajaran matematika dengan menggunakan media pembelajaran online merupakan salah satu bentuk realisasi dari kurikulum di program studi pendidikan matematika dan diharapkan mahasiswa dapat berperan aktif dan belajar mandiri pada mata kuliah kapita selekta matematika menengah sehingga dapat terhadap kemampuan koneksi matematis mahasiswa.

Kemampuan koneksi matematis mahasiswa merupakan kemampuan yang akan digali dalam penelitian ini. Kemampuan ini termasuk kemampuan berpikir tingkat tinggi dan akan digali melalui penggunaan media pembelajaran online. Kelebihan media online dalam menjelaskan suatu konsep matematika dapat menuntut mahasiswa untuk bereksplorasi dan menganalisis, mencoba dan menggali konsep dan prinsip yang termuat dalam suatu materi yang dihadapinya, sehingga relatif membangun struktur pemahaman mahasiswa. 
Penelitian ini bertujuan untuk mengembangkan dan menghasilkan suatu media pembelajaran online yang valid dan praktis dalam terhadap kemampuan koneksi matematis mahasiswa. Target khusus yang ingin dicapai dalam penelitian ini yakni meningkatnya kemampuan koneksi matematis mahasiswa program studi matematika Universitas Wiralodara Indramayu untuk mata kuliah Kapita Selekta Matematika Pendidikan Menengah. Tujuan tersebut didasarkan pada permasalahan bahwa media pembelajaran yang digunakan pada saat perkuliahan adalah media pembelajaran yang belum dikembangkan oleh dosen, mempersiapkan mengahadapi revolusi 4.0 dan kondisi pembelajaran yang menggunakan daring merupakan salah satu dampak dari Covid-19.

Tujuan dari penelitian ini adalah untuk merancang dan mengembangkan media pembelajaran berbasis online pada mata kuliah kapita selekta matematika menengah mahasiswa program studi pendidikan matematika. Secara rinci tujuan yang akan dicapai sebagai berikut: (1) merancang dan mengembangkan media pembelajaran berbasis online yang dapat digunakan untuk memfasilitasi belajar mandiri dalam mata kuliah kapita selekta matematika menengah; (2) mengukur kelayakan media pembelajaran yang dikembangkan berdasarkan penilaian ahli media pembelajaran dan ahli materi; (3) mengukur kemampuan koneksi matematis mahasiswa setelah menggunakan media pembelajaran ini.

\section{Metode Penelitian}

Penelitian ini merupakan penelitian pengembangan. Adapun yang dikembangkan adalah perangkat Media Pembelajaran Online yang terdiri dari silabus/Rencana Pembelajaran Semester (RPS), Satuan Acara Pembelajaran (SAP), Lembar Kegiatan Mahasiswa (LKM), Media Pembelajaran Online (MPO), dan Tes Kemampuan Koneksi Matematis (TKKM).

Pengembangan media pembelajaran online ini peneliti melakukan beberapa tindakan sebelum mendesain pengembangan media pembelajaran online diantaranya yaitu melakukan wawancara terhadap dosen matematika FKIP Universitas Wiralodra Indramayu mengenai permasalahan bahan ajar yang sering digunakan mahasiswa. Hasil wawancara tersebut dijadikan sebagai kerangka desain pengembangan media pembelajaran online yang valid dan praktis serta nantinya diuji cobakan kepada mahasiswa.

\section{Analisis Kevalidan Perangkat Pembelajaran}

\section{a. Analisis Data Validasi Perangkat Pembelajaran}

Perangkat pembelajaran yang sudah divalidasi ahli selanjutnya dianalisis secara deskriptif. Karena penskoran pada lembar validasi perangkat menggunakan rating scale maka menurut Sugiyono (2012: 142-144) teknik analisis datanya dilakukan sebagai berikut.

(1). Mencari jumlah skor kriterium, yaitu 4 kali banyaknya indikator penilaian yang dikembangkan, dimana 4 adalah skor tertinggi.

(2). Membuat rentang interval dari skor kriterium menjadi 4 kategori yaitu tidak baik, cukup baik, baik, dan sangat baik.

(3). Menentukan jumlah skor hasil pengumpulan data. 
(4). Menentukan posisi jumlah skor secara kontinu pada interval dan selanjutnya membuat kesimpulan tentang kualitas perangkat.

Kualitas perangkat dikatakan valid jika rata-rata jumlah skor hasil validasi dari validator terletak pada interval klasifikasi baik atau sangat baik. Kriteria penilaian perangkat pembelajaran dapat dilihat pada tabel di bawah ini.

Tabel 1 Kriteria Penilaian Validator

\begin{tabular}{lll}
\hline Rata-rata Nilai & Klasifikasi & Kesimpulan \\
\hline $1,00 \leq V a<1,76$ & tidak valid & perangkat masih memerlukan konsultasi intensif \\
$1,76 \leq V a<2,51$ & kurang valid & perangkat dapat digunakan dengan banyak revisi \\
$2,51 \leq V a<3,26$ & valid & perangkat dapat digunakan dengan sedikit revisi \\
$3,26<V a \leq 4,00$ & sangat valid & perangkat dapat digunakan tanpa revisi \\
\hline
\end{tabular}

Keterangan: $V a=$ rata-rata penilaian ahli

(Hobri, 2010: 53)

\section{b. Analisis Instrumen Soal TKKM}

TKKM digunakan untuk memperoleh data tentang hasil belajar matematika mahasiswa. Dalam penelitian ini akan digunakan suatu instrumen untuk mengetahui hasil belajar mahasiswa yaitu dalam bentuk soal tes. Pada proses pengembangan instrumen soal TKKM dilakukan bimbingan dan konsultasi validasi isi kepada validator. Setelah TKKM siap maka dilakukan uji coba instrumen tes pada kelas uji coba soal TKKM, selanjutnya hasil dari uji coba dilakukan analisis uji validitas, uji reliabilitas, uji tingkat kesukaran, dan uji daya pembeda.

\section{Analisis Kepraktisan Pembelajaran}

\section{a. Analisis Data Keterlaksanaan Pembelajaran}

Untuk mengetahui tingkat keterlaksanaan pembelajaran maka harus ada pengamatan kemampuan dosen mengelola pembelajaran online. Pengamatan dilakukan selama proses pembelajaran oleh 2 orang pengamat yang berasal dari teman sejawat.

\section{b. Analisis Data Respon Mahasiswa terhadap Pembelajaran Online}

Data respon mahasiswa yang diperoleh dari pemberian angket/kuisioner dianalisis dengan menentukan banyaknya yang memberi jawaban bernilai respon positif dan negatif untuk kategori yang ditanyakan dalam angket. Respon positif artinya mahasiswa, merasa senang, berminat terhadap komponen pembelajaran. Respon negatif bermakna sebaliknya.

\section{c. Analisis Respon Dosen terhadap Pembelajaran Online}

Data hasil pengisian angket respon dosen terhadap perangkat pembelajaran online dianalisis dengan menggunakan kriteria penilaian angket respon dosen yang terdiri atas 5 skor. Dalam melakukan dan memberikan penilaian pada lembar angket respon dosen digunakan pedoman penilaian (rubrik) yang telah disiapkan sebelumnya. 


\section{Hasil dan Pembahasan}

\section{Hasil dan Pembahasan Validasi serta Revisi terhadap Perangkat Pembelajaran}

Validasi ahli dilakukan untuk mendapatkan saran perbaikan sekaligus merupakan penilaian para ahli terhadap rancangan perangkat pembelajaran. Saran dari para ahli tersebut digunakan sebagai landasan penyempurnaan perangkat pembelajaran.

Secara umum hasil validasi para ahli terhadap perangkat pembelajaran diperoleh sebagai berikut:

1) Silabus/RPS kriteria sangat baik dan dapat digunakan dengan sedikit revisi.

2) SAP kriteria sangat baik dan dapat digunakan dengan sedikit revisi.

3) LKM kriteria sangat baik dan dapat digunakan dengan sedikit revisi.

4) MPO kriteria sangat baik dan dapat digunakan dengan sedikit revisi.

5) TKKM kriteria sangat baik dan dapat digunakan dengan sedikit revisi.

Beberapa revisi yang dilakukan terhadap Silabus/RPS, SAP, LKM, MPO, dan TKKM dapat dijelaskan sebagai berikut.

Tabel 2 Hasil penilaian validator terhadap perangkat pembelajaran

\begin{tabular}{clccccccc}
\hline \multirow{2}{*}{ No. } & Perangkat & \multicolumn{4}{c}{ Validator } & Rata- & \multirow{2}{*}{ Klarifikasi } \\
\cline { 3 - 6 } & Pembelajaran & I & II & III & IV & V & rata & \\
\hline 1. & Silabus/RPS & 3,72 & 3,80 & 3,50 & 3,90 & 3,80 & 3,72 & Sangat Baik \\
2. & SAP & 3,75 & 3,88 & 3,88 & 3,94 & 4,00 & 3,89 & Sangat Baik \\
3. & LKM & 3,42 & 3,83 & 3,08 & 4,00 & 4,00 & 3,67 & Sangat Baik \\
4. & MPO & 3,64 & 3,55 & 3,73 & 4,00 & 4,00 & 3,78 & Sangat Baik \\
5. & TKKM & 3,55 & 3,73 & 3,55 & 4,00 & 4,00 & 3,76 & Sangat Baik \\
\hline
\end{tabular}

Berdasarkan hasil validasi ahli terhadap perangkat pembelajaran pada Tabel 2 menunjukkan bahwa perangkat yang dikembangkan mempunyai rata-rata pada interval 3,50 - 4,00 dengan klasifikasi sangat baik. Berikut adalah hasil validasi akhir dari perangkat pembelajaran yang dikembangkan akan diuraikan sebagai berikut:

a. Secara umum silabus/RPS yang telah dikembangkan dinilai sangat baik oleh validator dengan sedikit revisi diantaranya: kegiatan pembelajaran diberi nama dan modulnya, indikator disusun tiap pertemuan, pada penilaian harus diberi contoh.

b. Secara umum validator memberikan penilaian sangat baik dan dapat digunakan dengan sedikit revisi pada SAP. Beberapa hal yang menjadi catatan adalah tujuan dibuat operasional, kegiatan perkuliahan harus sesuai dengan skenario, perlu adanya legalisasi pengesahan, perhatikan tata tulis.

c. Secara umum validator memberikan penilaian sangat baik pada LKM dan dapat digunakan dengan revisi sedikit. Masukan untuk LKM seputar belum terlihat membimbing, tidak ada kunci jawaban, perhatikan materi yang konsepannya belum jelas, simbol matematika masih kurang digunakan.

d. Pada umumnya validator memberikan penilaian sangat baik pada MPO dan dapat digunakan dengan sedikit revisi. masukannya buatlah akses agar tidak terbatas, perlu dicantumkan tujuan perkuliahan, pertanyaan dalam indikator perlu lebih rinci, hilangkan hal-hal yang tidak diperlukan pada perkuliah. 
e. Secara umum TKKM siswa dinilai sangat baik dengan sedikit revisi. Masukan seputar skor penilaian, tata tulis matematika, membuat soal-soal dengan langkahlangkahnya, buat soal cadangan, tanda baca saja sehingga dapat dilakukan dengan cepat. Sebelum TKKM dipakai untuk mengambil data, dilakukan uji coba TKKM. Berdasarkan data hasil uji coba dilakukan uji validitas, reliabilitas, tingkat kesukaran dan daya beda soal untuk mengetahui kelayakan soal. Hasil analisis dan uji coba perangkat tes selengkapnya tersaji pada tabel 3 berikut ini.

Tabel 3 Hasil Analisis Data Uji Coba Perangkat TKKM

\begin{tabular}{|c|c|c|c|c|c|c|c|c|c|}
\hline \multirow[b]{2}{*}{$\begin{array}{l}\text { No. } \\
\text { Soal }\end{array}$} & \multirow[b]{2}{*}{ Indikator } & \multicolumn{2}{|c|}{ Validitas } & \multicolumn{2}{|c|}{ Reliabilitas } & \multicolumn{2}{|c|}{$\begin{array}{c}\text { Tingkat } \\
\text { Kesukaran }\end{array}$} & \multicolumn{2}{|c|}{$\begin{array}{c}\text { Daya } \\
\text { Pembeda }\end{array}$} \\
\hline & & $\begin{array}{l}\text { Korelasi } \\
\text { Product } \\
\text { Moment }\end{array}$ & Kriteria & $\begin{array}{l}\text { Nilai } \\
\text { Alpha }\end{array}$ & Kriteria & IK & Kriteria & $\mathrm{DP}$ & Kriteria \\
\hline 1 & Hubungan antar topik & 0,42 & Sedang & & & 0,74 & Mudah & 0,32 & Cukup \\
\hline 2 & $\begin{array}{l}\text { Mencari koneksi satu } \\
\text { prosedur ke prosedur lain }\end{array}$ & 0,70 & Tinggi & & & 0,68 & Sedang & 0,45 & Baik \\
\hline 3 & $\begin{array}{l}\text { Hubungan berbagai } \\
\text { representasi }\end{array}$ & 0,69 & Tinggi & & & 0,63 & Sedang & 0,44 & Baik \\
\hline 4 & $\begin{array}{l}\text { Matematika dalam bidang } \\
\text { studi lain }\end{array}$ & 0,65 & Tinggi & & & 0,60 & Sedang & 0,27 & Cukup \\
\hline 5 & $\begin{array}{l}\text { Menilai keterkaitan antar } \\
\text { topic }\end{array}$ & 0,71 & Tinggi & & reabilitas & 0,64 & Sedang & 0,49 & Baik \\
\hline 6 & Hubungan antar topik & 0,74 & Tinggi & & tinggi & 0,64 & Sedang & 0,51 & Baik \\
\hline 7 & $\begin{array}{l}\text { Mencari koneksi satu } \\
\text { prosedur ke prosedur lain }\end{array}$ & 0,78 & Tinggi & & & 0,65 & Sedang & 0,46 & Baik \\
\hline 8 & $\begin{array}{l}\text { Hubungan berbagai } \\
\text { representasi }\end{array}$ & 0,85 & $\begin{array}{l}\text { tinggi } \\
\text { sekali }\end{array}$ & & & 0,43 & Sedang & 0,53 & Baik \\
\hline 9 & $\begin{array}{l}\text { Matematika dalam bidang } \\
\text { studi lain }\end{array}$ & 0,72 & Tinggi & & & 0,60 & Sedang & 0,51 & Baik \\
\hline 10 & $\begin{array}{l}\text { Menilai keterkaitan antar } \\
\text { topic }\end{array}$ & 0,76 & Tinggi & & & 0,56 & Sedang & 0,47 & Baik \\
\hline
\end{tabular}

Berdasarkan Tabel 3 soal nomor 1, 2, 3, 4, 5, 6, 7, 8, 9, dan 10 adalah soal-soal valid dengan kriteria sedang, tinggi, dan tinggi sekali. Mempunyai reabilitas yang tinggi, tingkat kesukaran dengan kriteria mudah dan sedang. Serta daya pembeda termasuk dalam kelompok kriteria cukup dan baik. Maka soal-soal tersebut dapat dipergunakan. Hal ini berarti dalam uji coba TKKM di kelas uji coba akan digunakan soal-soal nomor $1,5,7,8$, dan 9 .

\section{Hasil dan Pembahasan Uji Coba Perangkat Pembelajaran}

Setelah semua perangkat pembelajaran divalidasi dan TKKM dinyatakan layak untuk diuji cobakan, maka perangkat pembelajaran diuji cobakan pada kelas eksperimen MPO, sedangkan untuk soal TKKM diuji cobakan di kelas eksperimen MPO. Selama proses uji coba ini, dilakukan proses pengambilan data pengamatan aktivitas mahasiswa. Selanjutnya diakhir proses uji coba, dilakukan TKKM untuk mengukur kemampuan komunikasi matematis mahasiswa. 


\section{Hasil dan Pembahasan Kepraktisan Perangkat Pembelajaran}

\section{a. Hasil dan Pembahasan Keterlaksanaan Pembelajaran}

Hasil pengamatan kemampuan dosen mengelola pembelajaran matematika dengan media pebelajaran online untuk mencapai kemampuan komunikasi matematis mahasiswa diperoleh dari hasil observasi pelaksanaan pembelajaran dengan rata-rata skor 3,59 dari skala 4,00 berarti dalam kategori tinggi sehingga dapat dikatakan keterlaksanaan pembelajaran baik.

b. Hasil dan Pembahasan Respon Mahasiswa terhadap Perangkat Pembelajaran

Didapatkan respon mahasiswa dari pembelajaran MPO untuk mencapai kemampuan koneksi matematis adalah sebagai berikut.

Tabel 4 Pendapat Mahasiswa terhadap Komponen Mengajar

\begin{tabular}{|c|c|c|c|}
\hline No. & Keterangan & Senang $(\%)$ & Tidak Senang (\%) \\
\hline 1 & MPO & 87,5 & 12,5 \\
\hline 2 & LKM & 70 & 30 \\
\hline 3 & TKKM & 77,5 & 22,5 \\
\hline 4 & Suasana Pembelajaran di kelas & 77,5 & 22,5 \\
\hline 5 & Cara dosen mengajar & 85 & 15 \\
\hline
\end{tabular}

Tabel 5 Minat Mahasiswa untuk Mengikuti Pembelajaran Selanjutnya

\begin{tabular}{lcc}
\hline \multicolumn{1}{c}{ Keterangan } & Berminat (\%) & $\begin{array}{c}\text { Tidak Berminat } \\
(\%)\end{array}$ \\
\hline $\begin{array}{l}\text { Apakah mahasiswa berminat mengikuti } \\
\text { kegiatan belajar berikutnya dengan cara } \\
\text { seperti yang diikuti sekarang ini }\end{array}$ & 72,5 & 27,5 \\
\hline
\end{tabular}

Tabel 6 Komentar Mahasiswa terhadap Keterbacaan

\begin{tabular}{clccc}
\hline No. & & Keterangan & Ya $(\%)$ & Tidak $(\%)$ \\
\hline 1 & MPO & 82,5 & 17,5 \\
2 & LKM & 87,5 & 12,5 \\
3 & TKKM & 87,5 & 12,5 \\
\hline
\end{tabular}

Tabel 7 Ketertarikan dengan Penampilan Media Pembelajaran Online

\begin{tabular}{lcc}
\hline \multicolumn{1}{c}{ Keterangan } & Ya (\%) & Tidak (\%) \\
\hline $\begin{array}{l}\text { Apakah mahasiswa tertarik pada } \\
\text { penampilan (tulisan, gambar, letak) }\end{array}$ & 92,5 & 7,5 \\
yang terdapat pada MPO. & & \\
\hline
\end{tabular}

Dengan demikian dari tabel respon diatas menghasilkan rata-rata respon positif mahasiswa terhadap pembelajaran adalah $82 \%$, sehingga dapat disimpulkan perangkat pembelajaran tersebut praktis.

\section{Hasil dan Pembahasan Respon Dosen terhadap Perangkat Pembelajaran}

Data yang ditunjukkan dari respon dosen diperoleh hasil sebagai berikut.

a. Penilaian Bapak/Ibu dosen terhadap setiap perangkat pembelajaran dan instrumen menunjukkan hasil yang baik dan sangat baik. 
b. Ketertarikan Bapak/Ibu dosen terhadap pemakaian perangkat pembelajaran dan instrumen menunjukkan hasil ingin memakai dan sangat ingin memakai perangkat tersebut.

c. Pendapat Bapak/Ibu dosen terhadap perangkat pembelajaran dan instrumen ini kaitannya dengan tugas mengajar Bapak/Ibu menunjukkan hasil bahwa perangkat serta instrumen membantu dan sangat membantu dalam tugas mengajar Bapak/Ibu dosen.

\section{Kesimpulan}

Berdasarkan proses pengembangan yang telah diuraikan maka diperoleh beberapa kesimpulan sebagai berikut:

Perangkat media pembelajaran online terhadap kemampuan koneksi matematis mahasiswa dikatakan valid karena telah melalui proses validasi dan dinyatakan memenuhi validitas isi dan validitas konstruk yang ditetapkan oleh ahli/pakar dibidangnya. Perangkat pembelajaran yang diperoleh terdiri dari Silabus/RPS, SAP, LKM, MPO, dan TKKM.

a. Perangkat media pembelajaran online dikatakan praktis, karena telah memenuhi indikator praktis sebagai berikut.

b. Pelaksanaan dengan media pembelajaran online berhasil berjalan dengan baik.

c. Pelaksanaan dengan media pembelajaran online mendapatkan respon positif dari mahasiswa.

d. Pelaksanaan dengan media pembelajaran online mendapatkan respon baik dan sangat baik dari dosen.

\section{Pustaka}

Anggara, B. 2014. Konsep Dasar E-Learning dan Online Learning.

https://anggaradian.wordpress.com/2014/12/05/konsep-e-learning-dan-online-

learning/ Diakses pada tanggal 15 Agustus 2019.

Departemen Pendidikan Nasional. 2013. Peraturan Menteri Pendidikan dan

Kebudayaan Republik Indonesia Nomor 65 Tahun 2013, tentang Standar Proses.

Hendriana, H, dkk. 2017. Hard Skills dan Soft Skills Matematik Siswa. Bandung: PT. Refika Aditama.

Hobri. 2010. Metodelogi Penelitian Pengembangan (Aplikasi Pada Penelitian Pendidikan Matematika). Jember: Pena Salsabila

Kementerian Pendidikan dan Kebudayaan. 2016. Peringkat dan Capaian PISA

Indonesia Mengalami Peningkatan.

https://www.kemdikbud.go.id/main/blog/2016/12/peringkat-dan-capaian-pisaindonesia-mengalami-peningkatan. Diakses pada tanggal 5 Agustus 2019. 
Saluky. 2016. "Pengembangan Bahan Ajar Matematika Berbasis Web dengan Menggunakan Wordpress". EduMa. Volume 5, No. 1. Hal 80 - 89

Sugiyono. 2017. Metode Penelitian Kuantitatif, Kualitatif, dan R\&D. Bandung: Alfabeta, CV.

Sumarmo, U. 2012. Pendidikan Karakter serta Pengembangan Berpikir dan Diposisi Matematik dalam pembelajaran Matematika. Nasional Seminar of Mathematics Education at Widya Mandira Katholic University Kupang NTT, April 2012. Makalah dimuat dalam Suryadi, D, Turmudi, Nurlaelah, E. (Editor). Kumpulan Makalah Proses Berpikir dan Disposisi Matematik dan Pembelajarannya. 2014. Hal. 333 - 373. Jurusan Pendidikan Matematika FPMIPA UPI.

Wahyudin, K., dan Purniati, T. 2010. Upaya Terhadap Pencapaian Belajar Mahasiswa pada Perkuliahan Kapita Selekta Matematika Sekolah melalui Pembelajaran Resiprokal. Bandung: FPMIPA UPI.

Wardani, S, dkk. 2013. "Pengembangan Media Pembelajaran Berbasis Multimedia Interaktif Untuk Memfasilitasi Belajar Mandiri Mahasiswa Pada Mata Kuliah Kapita Selekta Kuliah Kapita Selekta Matematika". Jurnal Pengajaran MIPA, Volume 18, No. 2. Hal. 167 - 177. 
